\title{
Changes in the sodium content of bread in Australia and New Zealand between 2007 and 2010: implications for policy
}

\section{Elizabeth K Dunford \\ MPH, Research Office Food Policy Division \\ Helen Eyles MSc, PhD, Research Fellow/Nutritionist \\ Cliona Ni Mhurchu BSc(Hons), PhD, Associate \\ Jacqui L Webste MA, PhD, Senior Project Manager, Food Policy Division \\ Bruce C Neal MB ChB, PhD Senior Director \\ 1 The George Institut for Global Health Sydney, NSW. \\ 2 Clinical Trials Research Unit, University of Auckland Auckland, New Zealand. \\ edunford@ georgeinstitute.org.au}

MJA 2011; 195: 346-349 doi:10.5694/mjall.10673 $t$ is well established that excess dietary sodium consumed throughout life causes blood pressure to rise with age ${ }^{1,2}$ and greatly increases the risks of cardiovascular diseases. ${ }^{3,4}$ With average population sodium consumption accepted to be well above recommended dietary intakes in both Australia ${ }^{5}$ and New Zealand, ${ }^{6}$ efforts are increasingly focused on reducing population sodium intake. ${ }^{7,8}$ There is particular interest in strategies involving the food industry because some threequarters of the sodium in Australian and New Zealand diets derives from processed foods. ${ }^{9}$ In both countries, bread is one of the biggest contributors, providing about a fifth of daily sodium intake. ${ }^{6,9}$

In 2007, the New Zealand Heart Foundation and the Australian Division of World Action on Salt and Health each launched new efforts to engage industry in new programs to reduce the sodium content of bread. ${ }^{10}$ More recently, in 2010, the Australian Government's Food and Health Dialogue announced a voluntary sodium target for Australian breads. ${ }^{11}$ Several bread manufacturers have made commitments to reducing the salt content of their breads in both countries, ${ }^{10,11}$ and reformulation to reduce the sodium content of food is now firmly on the agenda in Australia and New Zealand. ${ }^{12}$

The primary objective of this study was to establish the effectiveness of recent efforts to achieve reductions in the sodium content of bread products in Australia and New Zealand. ${ }^{11,13}$

\section{Methods}

Data on sodium content were collected for sliced packaged breads available for sale in Australia and New Zealand in 2007 and 2010. Data were obtained directly from the mandatory Nutrition Information Panel (NIP) of

Objective: To define the effectiveness of recent efforts by the Australian Division of World Action on Salt and Health, and the Heart Foundation in New Zealand to reduce sodium levels in breads in Australia and New Zealand.

Design and setting: Data on the sodium contents of packaged sliced bread products sold in Australian and New Zealand supermarkets were collected from the product labels of 157 breads in 2007 and 167 breads in 2010, and were compared overall, by bread type, by manufacturer, and between nations.

Main outcome measures: Mean sodium values in bread and proportions of breads meeting the targets of $400 \mathrm{mg} / 100 \mathrm{~g}$ in Australia and $450 \mathrm{mg} / 100 \mathrm{~g}$ in New Zealand.

Results: Overall mean sodium content in bread in Australia was $434 \mathrm{mg} / 100 \mathrm{~g}$ in 2007 and $435 \mathrm{mg} / 100 \mathrm{~g}$ in 2010; corresponding values for New Zealand were $469 \mathrm{mg} / 100 \mathrm{~g}$ and $439 \mathrm{mg} / 100 \mathrm{~g}$. The proportion of Australian breads meeting the national target increased from $29 \%$ in 2007 to $50 \%$ in 2010; the proportion of New Zealand breads meeting the national target increased from 49\% in 2007 to $90 \%$ in 2010 . There were clear differences between the results achieved by different companies.

Conclusions: Voluntary efforts by non-governmental organisations have had some impact on sodium levels in bread, particularly in New Zealand. However, substantial room for further improvement remains. If additional reductions are not achieved under the current voluntary arrangements, legislated approaches may be required.

all packaged breads identified during visits to two major supermarket chains in each country (Coles and Woolworths in Australia and Pak'n Save and Foodtown/Countdown in New Zealand).

For each bread product, the brand name, product name, manufacturer and sodium content per $100 \mathrm{~g}$ were recorded on paper data collection forms in the supermarket and subsequently entered into an electronic spreadsheet. Each bread product was categorised as "white", "wholemeal" or "mixed grain".

\section{Data analysis}

The mean, median, standard deviation, and range of sodium content were calculated overall, by country, by bread type, by year and by manufacturer. The proportion of Australian products meeting the Australian Food and Health Dialogue sodium target of $400 \mathrm{mg} / 100 \mathrm{~g}^{11}$ and the proportion of New Zealand products meeting the Heart Foundation Project Target 450 target value ${ }^{10}$ of $450 \mathrm{mg} / 100 \mathrm{~g}$ were also calculated for 2007 and 2010

\section{Results}

In Australia, sodium content data were available for 94 sliced bread products in 2007 and 99 in 2010. For New Zealand, the corresponding numbers were 63 and 68 . For every bread type, sodium content per $100 \mathrm{~g}$ varied substantially across years and countries, indicating marked initial and subsequent variation in bread composition (Box 1).

\section{Sodium content of breads in 2010}

In 2010, the overall average levels of sodium in Australian breads and New Zealand breads were the same $(435 \mathrm{mg} / 100 \mathrm{~g})$. Similarly, overall mean sodium levels did not vary much by bread type (white, $436 \mathrm{mg} /$ $100 \mathrm{~g}$; wholemeal, $421 \mathrm{mg} / 100 \mathrm{~g}$; and mixed grain, $438 \mathrm{mg} / 100 \mathrm{~g}$ ), although there were differences between the mean sodium contents of breads produced by different manufacturers. In Australia, for example, the mean sodium content of breads produced by George Weston Foods (394 mg/ $100 \mathrm{~g}$ ) was lower than that of breads produced by Goodman Fielder 
(455 mg/100 g). Analyses by country showed additional variation in the mean sodium content of breads that is not apparent from the overall analyses (Box 1 and Box 2). For example, the bread types with the highest mean sodium content in Australia in 2010 were mixed grain $(450 \mathrm{mg} /$ $100 \mathrm{~g})$ followed by white $(427 \mathrm{mg} /$ $100 \mathrm{~g}$ ) and wholemeal (409 mg/ 100 g). In New Zealand, the pattern was different, with white bread $(463 \mathrm{mg} / 100 \mathrm{~g})$ having the highest sodium content, followed by wholemeal (449 mg/100 g) and mixed grain (426 mg/100 g).

\section{Changes in mean sodium content between 2007 and 2010}

The mean sodium content of bread products in Australia did not fall over the 4-year study period, with a mean sodium content of $434 \mathrm{mg} / 100 \mathrm{~g}$ in 2007 and $435 \mathrm{mg} / 100 \mathrm{~g}$ in 2010. However, in New Zealand, there was a 7\% reduction over the same time period, from $469 \mathrm{mg} / 100 \mathrm{~g}$ to $435 \mathrm{mg} / 100 \mathrm{~g}$, bringing mean sodium levels in New Zealand breads in line with those of Australian breads. The mean sodium content of the different bread types varied between countries and between manufacturers (Box 2 and Box 3).

\section{Changes in the proportion of breads meeting established sodium targets between 2007 and 2010}

The proportion of Australian bread products meeting the $400 \mathrm{mg} / 100 \mathrm{~g}$ Australian target increased from 29\% in 2007 to $50 \%$ in 2010. In New Zealand, there was also an increase in the proportion of products meeting the Heart Foundation $450 \mathrm{mg} / 100 \mathrm{~g}$ target, from $49 \%$ in 2007 to $90 \%$ in 2010 (Box 1). The proportion of each type of bread (white, wholemeal, mixed grain) that met sodium content targets was mostly greater in 2010 than in 2007 (Box 1)

\section{Discussion}

Our findings demonstrate the potential for voluntary salt reduction programs, implemented as collaborations between non-governmental agencies and industry, to effect changes in the sodium content of bread. Our data also highlight the need for sustained

1 Changes in mean sodium content of Australian and New Zealand breads and proportions meeting targets between 2007 and 2010

\begin{tabular}{|c|c|c|c|c|}
\hline \multirow[b]{2}{*}{ Breads } & \multicolumn{2}{|c|}{ Australia } & \multicolumn{2}{|c|}{ New Zealand } \\
\hline & 2007 & 2010 & 2007 & 2010 \\
\hline \multicolumn{5}{|l|}{ White breads } \\
\hline No. of products & 28 & 33 & 16 & 12 \\
\hline \multicolumn{5}{|l|}{ Sodium content (mg/100 g) } \\
\hline Mean (SD) & $425(75)$ & $427(73)$ & $519(45)$ & $463(63)$ \\
\hline Median & 450 & 400 & 535 & 450 \\
\hline Range & $200-523$ & $250-561$ & $447-600$ & $400-630$ \\
\hline Proportion $\leqslant 400 \mathrm{mg} / 100 \mathrm{~g} *$ & $25 \%$ & $55 \%$ & 0 & $17 \%$ \\
\hline Proportion $\leqslant 450 \mathrm{mg} / 100 \mathrm{~g}^{\dagger}$ & $68 \%$ & $76 \%$ & $20 \%$ & $83 \%$ \\
\hline \multicolumn{5}{|l|}{ Wholemeal breads } \\
\hline No. of products & 18 & 16 & 7 & 7 \\
\hline \multicolumn{5}{|l|}{ Sodium content (mg/100 g) } \\
\hline Mean (SD) & $420(98)$ & $409(52)$ & $453(53)$ & $449(27)$ \\
\hline Median & 450 & 400 & 459 & 450 \\
\hline Range & $115-500$ & $243-470$ & $377-520$ & $420-505$ \\
\hline Proportion $\leqslant 400 \mathrm{mg} / 100 \mathrm{~g} *$ & $28 \%$ & $56 \%$ & $29 \%$ & 0 \\
\hline Proportion $\leqslant 450 \mathrm{mg} / 100 \mathrm{~g}^{\dagger}$ & $56 \%$ & $81 \%$ & $43 \%$ & $86 \%$ \\
\hline \multicolumn{5}{|l|}{ Mixed grain breads } \\
\hline No. of products & 48 & 50 & 40 & 49 \\
\hline \multicolumn{5}{|l|}{ Sodium content (mg/100 g) } \\
\hline Mean (SD) & $444(61)$ & $450(96)$ & $452(60)$ & $426(46)$ \\
\hline Median & 450 & 420 & 423 & 420 \\
\hline Range & $310-620$ & $235-770$ & $377-550$ & $330-590$ \\
\hline Proportion $\leqslant 400 \mathrm{mg} / 100 \mathrm{~g} *$ & $31 \%$ & $44 \%$ & $28 \%$ & $31 \%$ \\
\hline Proportion $\leqslant 450 \mathrm{mg} / 100 \mathrm{~g}^{\dagger}$ & $56 \%$ & $66 \%$ & $63 \%$ & $92 \%$ \\
\hline \multicolumn{5}{|l|}{ All breads } \\
\hline No. of products & 94 & 99 & 63 & 68 \\
\hline \multicolumn{5}{|l|}{ Sodium content (mg/100 g) } \\
\hline Mean (SD) & $434(73)$ & $435(84)$ & $469(62)$ & $435(50)$ \\
\hline Median & 450 & 402 & 459 & 435 \\
\hline Range & $115-620$ & $235-770$ & $340-600$ & $330-630$ \\
\hline Proportion $\leqslant 400 \mathrm{mg} / 100 \mathrm{~g} *$ & $29 \%$ & $50 \%$ & $20 \%$ & $25 \%$ \\
\hline Proportion $\leqslant 450 \mathrm{mg} / 100 \mathrm{~g}^{\dagger}$ & $60 \%$ & $72 \%$ & $49 \%$ & $90 \%$ \\
\hline
\end{tabular}

action, because there is still substantial room for improvement. While the concerted efforts over 4 years of these agencies and their collaborating manufacturers has reduced the mean sodium content of New Zealand breads, there has been no corresponding reduction in mean levels in Australia. The proportion of breads meeting targets did rise in both countries, but an isolated change in this parameter is unlikely to translate into large health gains. There remains substantial scope for improvement, ${ }^{11,14}$ with the mean sodium content of breads in Australia and New Zealand still far higher than that in the United Kingdom (397 mg/100 g). ${ }^{15,16}$
The wide range of sodium levels we identified $(115 \mathrm{mg} / 100 \mathrm{~g}$ to $770 \mathrm{mg} /$ $100 \mathrm{~g}$ ) indicates that it is possible to manufacture and market breads with low sodium content, and suggests that the barriers are mostly not technical. ${ }^{17}$ Coordinating salt reduction efforts may have significant potential for delivering improvements. This is highlighted by the disparities observed for the two manufacturers in this study that operate in both Australia and New Zealand (George Weston Foods and Goodman Fielder). In 2010 in Australia, the breads of George Weston Foods had a lower mean sodium content than the breads of Goodman Fielder, but the reverse 
2 Mean sodium content ( $\mathrm{mg} / 100 \mathrm{~g}$ ) in bread in 2007 and 2010, by manufacturer

\begin{tabular}{|c|c|c|c|c|}
\hline \multirow[b]{2}{*}{ Manufacturer } & \multicolumn{2}{|r|}{2007} & \multicolumn{2}{|r|}{2010} \\
\hline & $\begin{array}{l}\text { No. of } \\
\text { breads }\end{array}$ & $\begin{array}{c}\text { Mean sodium content } \\
\text { (range) }\end{array}$ & $\begin{array}{l}\text { No. of } \\
\text { breads }\end{array}$ & $\begin{array}{c}\text { Mean sodium content } \\
\text { (range) }\end{array}$ \\
\hline \multicolumn{5}{|l|}{ Australia } \\
\hline Coles & 5 & $457(410-523)$ & 7 & $431(400-470)$ \\
\hline Woolworths & 9 & $477(440-500)$ & 8 & 394 (377-400) \\
\hline George Weston Foods & 31 & $444(366-505)$ & 25 & $394(280-430)$ \\
\hline Goodman Fielder & 43 & $415(115-560)$ & 38 & 455 (250-770) \\
\hline Other* & 10 & $454(260-620)$ & 19 & $473(235-660)$ \\
\hline \multicolumn{5}{|l|}{ New Zealand } \\
\hline Foodstuffs & 5 & $478(377-600)$ & 5 & $429(377-450)$ \\
\hline Progressive & 11 & $443(377-545)$ & 3 & $450(450)$ \\
\hline George Weston Foods & 12 & $474(390-548)$ & 28 & $446(330-630)$ \\
\hline Goodman Fielder & 32 & $469(380-550)$ & 36 & $435(370-550)$ \\
\hline Other ${ }^{\dagger}$ & 3 & $532(498-575)$ & 0 & - \\
\hline
\end{tabular}

* Includes data from nine other minor manufacturers in Australia. † Includes data from one other minor manufacturer in New Zealand. corresponding improvement in mean salt levels) will have reduced the total quantity of salt delivered to the Australian population in bread. In New Zealand, where there were improvements in both the proportion of products meeting the target and the overall mean sodium level, there is likely to have been a real fall in the amount of salt delivered to consumers in bread, with associated gains in public health.

A limitation of our study is that we did not weight sodium data by sales. Market-share data for each product would have enabled an analysis that directly quantified the impact of the changes observed on the quantity of sodium in bread products sold. ${ }^{21}$ Reassuringly, the mean sodium levels in Australia were consistent with previous data reported from sales-weighted analyses done by the national Heart Foundation in $2009 .{ }^{22}$ It is also of note that the data we present here do not include unpackaged breads and breads sold from non-supermarket outlets. In Australia, for example, it is known that Bakers Delight products have sodium levels significantly above the average. ${ }^{23}$

In conclusion, our data provide the first objective, quantitative evaluation of progress in reducing the sodium content of bread products in Australia and New Zealand. While there has been some improvement in sodium levels in New Zealand, and while the companies actively engaged in salt reduction efforts are to be congratulated, our data also highlight the need for continued action. Better results are likely to be achieved if the governments of Australia and New Zealand take committed leadership of these programs.

\section{Changes in the sodium content of bread, 2007-2010*}
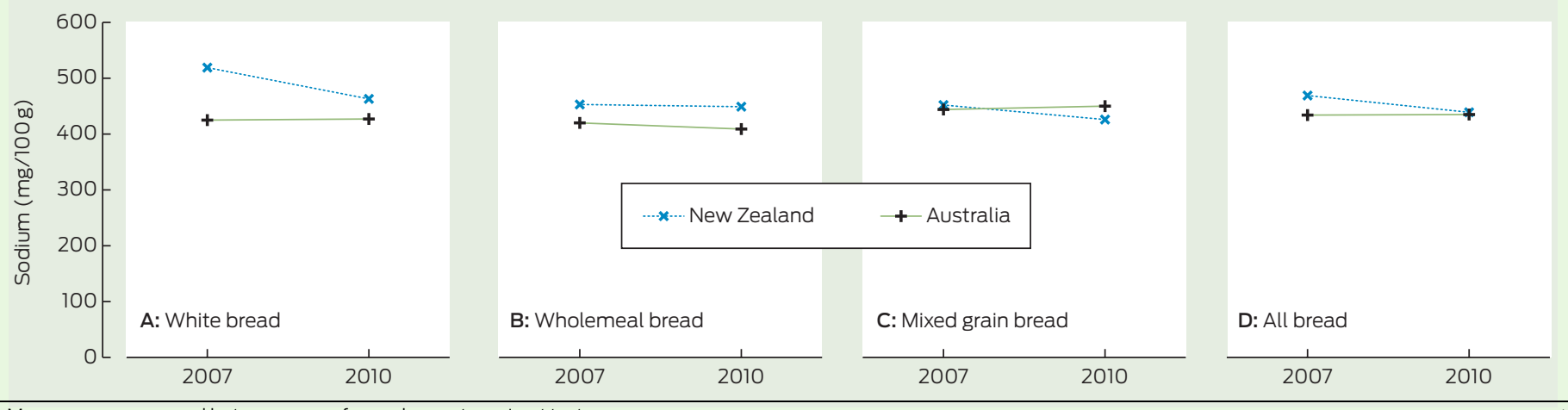

* Means were compared between years for each country using $t$ tests. 
Acknowledgements: Elizabeth Dunford is supported by a Sydney Medical School Foundation scholarship; Cliona Ni Mhurchu holds the Heart Foundation of New Zealand Senior Fellowship (Grant 1380). Bruce Neal is supported by an Australian Research Council Future Fellowship. Main project funding was provided by a National Health and Medical Research Council of Australia Partnership Grant with partner support from the Australian Division of World Action on Salt and Health, the Australian Food and Grocery Council, New South Wales Health and the New South Wales Food Authority.

Competing interests: Jacqui Webster is the Senior Project Manager, Elizabeth Dunford is the Research Officer and Bruce Neal is the Chairman of the Australian Division of World Action on Salt and Health. Jacqui Webster was previously responsible for implementing the United Kingdom Food Standards Agency salt reduction strategy, including the initial consultation on salt targets.

Received 29 May 2011, accepted 27 Jul 2011.

1 Havas S, Dickinson B, Wilson M. The urgent need to reduce sodium consumption. JAMA 2007; 298: 1439-1441.

2 Intersalt Cooperative Research Group. Intersalt: an international study of electrolyte excretion and blood pressure. Results for 24 hour urinary sodium and potassium excretion. BMJ 1988; 319 328.

3 Asia Pacific Cohort Studies Collaboration. Blood pressure and cardiovascular diseases in the AsiaPacific region. J Hypertens 2003; 21: 707-716.

4 Beaglehole R, Bonita R, Horton R, et al. Priority actions for the non-communicable disease crisis. Lancet 2011; 377: 1438-1447.

5 Australian Government National Health and Medical Research Council. Nutrient reference values for Australia and New Zealand including recommended dietary intakes. Canberra: NHMRC, 2006. http://www.nhmrc.gov.au/ guidelines/publications/n35-n36-n37 (accessed Aug 2011)

6 NZ Ministry of Health; University of Auckland. Nutrition and the burden of disease. New
Zealand 1997-2011. Wellington: NZ Ministry of Health and the University of Auckland, 2003.

7 Campbell NR, Neal BC, Macgregor GA. Interested in developing a national programme to reduce dietary salt? J Hum Hypertens 2011; 31 Mar [epub ahead of print].

8 Webster J, Dunford E, Huxley R, et al. The development of a national salt reduction strategy for Australia. Asia Pac J Clin Nutr 2009; 18: 303-309.

9 Food Standards Australia New Zealand. Proposa P230. Consideration of mandatory fortification with iodine. Canberra: FSANZ, 2007.

10 Heart Foundation (NZ). Reducing our sodium footprint. Feb 2010. http://www.heart foundation.org.nz/uploads/Project\%20Heart SAFE Situation\%20Analysis Sodium Final\%20 (removing\%20the $\% 20$ word\%20project $\% 20$ fro m\%20title).pdf (accessed Aug 2011).

11 The Hon Mark Butler MP, Parliamentary Secretary for Health. Salt reduction targets agreed. 22 March 2010. Canberra: Australian Government Department of Health and Ageing 2010. http://www.health.gov.au/internet/ ministers/publishing.nsf/Content/mr-yrl0-mbmb022.htm?OpenDocument (accessed Dec 2010)

12 Food Industry Group (NZ). Annual report, March 2009. Auckland: FIG, 2009. http://www.fig org.nz/Resources/Library/Documents/reports/ Annual_report_2009.pdf (accessed Oct 2010).

13 Heart Foundation (Aust). Heart Foundation Tick. http://www.heartfoundation.org au/ information-for-professionals/heartfoundation-tick/pages/default.aspx (accessed Aug 2010)

14 New Zealand Food Safety Authority. Salt reduction at heart of new agreement [media release]. 10 Jun 2010. http://www.foodsafety. govt.nz/elibrary/industry/Salt_ReductionAligning_Efforts.htm (accessed Aug 2011).
15 Food Standards Agency (UK). Salt reduction targets Mar 2009. http://www.food.gov.uk/ multimedia/spreadsheets/salttargets2010 2012.xls (accessed Dec 2010).

16 Food Standards Agency (UK). Proposals to revise the voluntary salt reduction targets. $22 \mathrm{Jul} 2008$. http://www.food.gov.uk/consultations/ ukwideconsults/2008/saltreductiontargets (accessed Dec 2010)

17 Girgis S, Neal B, Prescott J, et al. A one-quarter reduction in the salt content of bread can be made without detection. Eur J Clin Nutr 2003; 57 : 616-620.

18 Pietinen P, Valsta LM, Hirvonen T, Sinkko H. Labelling the salt content in foods: a useful tool in reducing dietary sodium intake in Finland. Public Health Nutr 2008; 11: 335-340.

19 New York City Department of Health and Mental Hygiene. Cutting salt, improving health. http:// www.nyc.gov/html/doh/html/cardio/cardiosalt-initiative.shtml (accessed Oct 2010).

20 Health Canada. Sodium reduction strategy for Canada: recommendations from the Sodium Working Group. Jul 2010. http://www.hc-sc.gc.ca/ fn-an/nutrition/sodium/strateg/index-eng.php (accessed Oct 2010).

21 Webster JL, Dunford EK, Neal BC. A systematic survey of the sodium contents of processed foods. Am J Clin Nutr 2009; 91: 413-420.

22 Cleanthous X, Mackintosh AM, Anderson S. Breads in the current Australian market: sodium and fibre content report. Food Aust 2010; 62: 134136.

23 Australian Division of World Action on Salt and Health. Sodium content of Australian bread products 2007-2010. Nov 2010. http:// www.awash.org.au/documents/Bread\%20 report\%202010\%20FINAL.pdf (accessed Apr 2011) 